\title{
Work and Lives in Makassar Coastal Community: Assessing the Local Government Policy
}

\author{
Iin Karita Sakharina*, Aidir Amin Daud, Muh. Hasrul, Kadarudin, Hasbi Assidiq \\ Faculty of Law, Hasanuddin University, Indonesia. \\ * Corresponding author e-mail: ik.sakharina@gmail.com
}

\begin{tabular}{l} 
ARTICLE INFO \\
\hline Keywords: \\
Coastal Community; \\
Fisherman; Legal Policy; \\
Local Government \\
How to cite: \\
Sakharina, I.K., Daud, A.A., \\
Hasrul, M., Kadarudin., and \\
Assidiq, H. (2020). Work and \\
Lives in Makassar Coastal \\
Community: Assessing the \\
Local Government Policy \\
Hasanuddin Law Review, 6 \\
(1): 89-99 \\
DoI: \\
10.20956/halrev.v6i1.2281 \\
\hline
\end{tabular}

\begin{abstract}
The Makassar City Regional Government formulated a policy that previously carried out Mapping conducted on the less prosperous Coastal community, so departing from the mapping results obtained then formulated a policy as in the development of human resources will be carried out in areas that most need to become a poverty pouch. Local government is the most relevant party to be responsible for increasing the budget. All components, which are responsible for improvement, for the Coastal community, and of course for all parties, who are responsible for improving the welfare of the Coastal community, each related agency provides a budget that is appropriate to the community's needs and the duties and functions of each of the relevant agencies. . In addition, it is in the interests of government policies that harm the Coastal community. The implementation of the reclamation policy which is detrimental to fisheries is of course counterproductive to other policies aimed at the welfare of the Coastal community.
\end{abstract}

Copyright (C) 2020 HALREV. All rights reserved.

\section{Introduction}

Indonesia is a country that has a stretch of coastline with a length of $81,000 \mathrm{KM}$, thus making the Indonesian sea and Indonesia's coastal areas contain abundant wealth and natural marine biological resources, such as fish, coral reefs, mangrove forests and so on. A wide and rich marine species and fishing potential where in the area of catching 6.4 million tons/year and general fishery potential of 305,650 tons/year and marine potential of approximately 4 billion USD/ year. ${ }^{1}$ However, as it turns out into practice,

Supridi \& Alimudin. (2001). Hukum Perikanan di Indonesia, Jakarta: Sinar Grafika, p. 2; Sea is one of the sources of wealth of a country, because it saves natural resources very much, be it fish, seaweed, rocks, coral, and others. One of the lucky countries by the grace of the god associated with the marine area is Indonesia, 
there are several major challenges faced by the Indonesian government policy. The complicated and inappropriate legal framework currently place in Indonesia has contributed to serious degradation of coastal and marine resources. ${ }^{2}$

Coastal communities in various regions in Indonesia are very viscous with the characteristic of low quality community resources due to lack of access to education and information and poverty due to inequality income and dependency on sea resources only. Although on the other hand it highly upholds local wisdom. Coastal communities have not been optimally reached by the government, both central and regional governments. Even the information related to policies that had been proclaimed by the government apparently did not reach the coastal communities. The socialization that has been carried out both by independent institutions (NGOs) and government agencies in general coastal communities are not represented even tend to be not on target.

Some coastal areas in Indonesia have high potential and strategic fishing areas so that inevitably the main livelihood for the main community living in the coastal area is by going to sea (fishing). ${ }^{3}$ The problem of poverty and income inequality of coastal communities is still a sad fact in the development of national economic development. Even though the economy continues to grow every year, there are still problems with coastal communities that have not yet been completely resolved. ${ }^{4}$ Therefore, in the strategic plan of the Ministry of Maritime Affairs and Fisheries of the Republic of Indonesia, there are two things to be achieved namely hoisting the Maritime and Fisheries Community Welfare Index from 40.5 in 2015 to 51 in 2019. The second target, the growth in Fisheries Gross Domestic Product (GDP) rose from 7\% in 2015 to $12 \%$ in 2019. Efforts to realize the objectives include the increasing of supervision of management of marine and fisheries resources, utilization of marine resources for economic development and welfare of fishermen and coastal communities. ${ }^{5}$ The strategic plan of the Ministry of Maritime Affairs and Fisheries of the Republic of Indonesia is then followed up by several laws and regulations, one of which is the Law of the Republic of Indonesia Number 7 of 2016 concerning Protection and Empowerment of Fishermen, Fish Hatchers and Salt Farmers which regulates the rights and obligations of Fishermen, Fish Hatchers, and Salt Fishers. Therefore, the welfare direction of Fish Cultivation Fishermen and Salt Farmers which consist of coastal communities can be improved.

In Law of the Republic of Indonesia Number 11 of 2005 concerning ratification of the International Covenant on Economic, Social, and Cultural Rights 1966 (International Covenant on Economic, Social and Cultural Rights) primarily in Articles 6 through Article 15 which regulates the Obligations of States Parties to recognize and guarantee economic, social and cultural rights contained in and recognized in the Covenant, the emphasis on the word guarantee is aimed at all citizens, including coastal communities. Other provisions contained in Article 16 to Article 22 of the International

See Abd. Asis, et.al., (2016). Strategic policy of the Government of Indonesia In the Field of Maritime and Fisheries Affairs, International Journal of Scientific and Research Publications, 6 (12): 238

2 Dirhamsyah, D. (2006). Indonesian legislative framework for coastal resources management: a critical review and recommendation. Elesevier: Ocean \& Coastal Management, 49(1-2): 68-92.

3 Abd. Asis, et.al., (2017). Hak-Kewajiban Nelayan dan Kelompok Nelayan Menurut UU RI Nomor 7 Tahun 2016, Jurnal Hukum Justitia 5 (1): 53

4 Although de jure Indonesia is known as one of the world's archipelagic countries. See Article 46 (a) and Article 47 paragraph (1) 1982 UNCLOS.

5 Kata Data, Bagaimana Tingkat Kesejahteraan Masyarakat Pesisir Indonesia?, Kata Data News and Research 16 January 2018 
Covenant on Economic, Social and Cultural Rights, where Indonesia as a party to the ratification party must report on the implementation of the covenant instrument taken, as well as follow up actions that can be carried out by the Economic and Social Council or the Economic and Social Council, or other UN organs.

South Sulawesi province is one of the provinces in Indonesia which geographically is an area of very large marine-based. The province of South Sulawesi has a coastline of $1,937 \mathrm{KM}$ and sea area of $266,877 \mathrm{KM}^{2}$. From 24 regencies/cities in South Sulawesi Province, 2/3 of them are regencies/cities that have coastal and sea areas. In addition, South Sulawesi Province has 263 small islands scattered in several districts/cities including Makassar City, Selayar Islands Regency, Bone Regency, and Pangkaje'ne and Kepulauan Regency (Pangkep). With such a geographical situation, the Province of South Sulawesi has enormous marine resource potential. As for some of the potential possessed by the above categories are the following: 6

a. Natural resources that can be recovered (renewable resources) such as fisheries, seaweed, mangrove forests, shrimp ponds, etc;

b. Non-renewable resources such as oil and gas resources and iron sand mining; and

c. Environmental services, such as marine tourism, ship industry, and transportation.

Education has a central role because every country competes in preparing a quality workforce who has skilled and educated abilities. Improvement of educational facilities and infrastructure within the fishing community will spur improvement in the quality of fishermen's human resources. The education provided is in the form of general education as well as an increase in the ability of fishermen to capture sea products. The lives of poor fishing communities close to the sea cause a high vulnerability to the health of the fishing community. Health insurance from the government will greatly help the family economy of fishermen. Allocation of expenditure that should be used for health costs can be utilized by fishermen for other living needs. The central government should also urge regional governments to pay more attention to the development of regional coastal areas. Local governments should give opportunities for fishing communities to be able to improve their economies. These assistances can be in the form of marine regulations that support small fishermen, training and subsidy of fish production needs, as well as the provision of fish cooling facilities that can be used by fishing communities. ${ }^{7}$ These types of Policies are the one that are needed by the coastal community of fishing families so that their livelihoods can be more prosperous. As is the insurance for fishermen that has been regulated in the law.

The potential wealth of marine resources in the province of South Sulawesi is certainly a gift as well as a disaster for the fishermen who live in coastal areas and the sea. In fact what happens socio-cultural and economic conditions of coastal communities, especially fishermen in this province are very concerning. The geographical condition of the South Sulawesi coastal area turns out to be inversely proportional to the conditions of the people residing in the region. Poverty and difficulties of life are an

6 Koalisi Pemerhati Wilayah Pesisir dan Laut, Gambaran Umum Wilayah Pesisir dan Laut Sulawesi Selatan, Article of 2012.

7 The Ministry of Marine Affairs and Fisheries Republic of Indonesia. Meningkatkan Kesejahteraan Masyarakat Pesisir, Available online at: https://news.kkp.go.id/index.php/meningkatkan-kesejahteraan-masyarakat-pesisir/ Accessed on Sept 22, 2015. 
objective picture of the condition of coastal communities / fishermen in South Sulawesi. One of the causes of poverty experienced by fishermen, especially traditional fishermen, is the monopoly of fishing and markets carried out by the fishing industries so that fishermen get only a small amount of catch at a relatively cheap price. While the cost to conduct fishing activity is fairly high. In addition, the master plan to accelerate the expansion of Indonesia's economic development (MPEI) makes the Province of South Sulawesi a priority area for investment in increasing sea products. By establishing a fishing industry, there are at least 3 problems that pose a threat to fishermen in South Sulawesi:8

1. Very strong capital rush to the coastal areas of South Sulawesi. This capital investment is realized in the form of mining companies operating in coastal areas. What makes it worse is that the mining company operates not so far from the fishing settlement, as happened in Panaikang Village, East Sinjai District, Sinjai Regency, and Selayar Islands Regency. As a result, in Panaikang Village after the iron sand mining company operated in their area, ecological damage and coastal areas occurred ranging from marine pollution, to rising sea water up to people's homes. This situation is a picture of management of marine resources that are not based on local communities or local fishermen.

2. The threat of coastal reclamation. The Provincial Government of South Sulawesi and the Makassar City Government are running a mega project Center Point of Indonesia (CPI) which will be the grandest business center in eastern Indonesia. This CPI mega project was built on an area of 600 hectares above the sea reclamation area. This project has destroyed the livelihoods of traditional "tude" catchers. The project has also made thousands of traditional fishermen switch professions as construction workers, to pedicab drivers. In addition to Makassar City, the beach reclamation plan will be carried out in Bantaeng Regency. The beach reclamation is carried out on a 1 hectare reclamation area on Seruni Beach, with a depth of 3 meters. The beach reclamation in Bantaeng Regency is planned for the construction of hotels, supermarkets, and entertainment venues.

3. Climate change. In South Sulawesi, climate change that occurs and is felt by all human beings in the world has influenced the catches of South Sulawesi fishermen. Changes in weather and increasing of sea water volume greatly leaves the fishermen helpless. It caused the fishermen to experience a shortage of catch as happened to fishermen in Situ Baru Village, Bulukumba Regency and fishermen in the District of Galesong Selatan, Takalar Regency.

Being in the triangle area of the world's coral reefs, making the Indonesian sea rich in a variety of marine life such as fish and coral reefs. Not surprisingly, Indonesia is one of the largest fish producers in the world, including for reef fish species. As a strategic commodity, coral fishing is one of our fishermen's most engaged activities. ${ }^{9}$ Coastal communities in South Sulawesi, which is indeed one of the provinces' bases, has significant marine potential. It should be noted primarily on the welfare side. This welfare is very broad in scope, including economic, social, cultural, educational, and health aspects. The problem that will be examined in this paper is how is the Makassar City Government's policies towards coastal communities and their implementation?

\footnotetext{
Koalisi Pemerhati Wilayah Pesisir dan Laut, Loc.Cit.

Abd. Asis, et.al., Persoalan Hukum Nelayan dan Kelompok Nelayan di Kabupaten Takalar, Jurnal Ilmu Hukum "The Juris" Vol. II No. 2 December 2018, p. 179; See also Munawir, Menilai Kepatuhan Nelayan Kabupaten Takalar dalam Perbaikan Perikanan Karang, WWF Indonesia, 2017, accessed at https://www.wwf.or.id/?54362/ Evaluating-the-Fishermens-Level-of-Compliance-in-Takalar-Regency-in-Coral-Fishery-Improvement
} 


\section{Method}

The type of research used is prescriptive research, 10 using a statutory and conceptual approach. ${ }^{11}$ Data collection techniques are carried out through library research by studying and analysing a number of national legal regulations and international agreements, textbooks, research reports, legal journals, legal dictionaries, and supplemented with interviews, then analyzed descriptively.

\section{Policy of the Government of Makassar concerning Coastal Community}

As one of the coastal cities in Indonesia, Makassar City has a coastline of $32 \mathrm{~km}$ and covers 11 small islands with a total area of 122,370 hectares or around $1.1 \%$ of the land area. That fact makes Makassar City has various uniqueness as a coastal city. In recent years, coastlines in several regions in Indonesia have experienced quite a narrowing, according to an article from the Review of Spatial Planning Aspects in Marine and Coastal Area Management, by the Minister of Settlements and Regional Infrastructure, 2003 pages 10-11, Makassar City is one of the 30 coastal cities in Indonesia which is estimated to be potentially affected by rising sea levels.

Some basic assumptions about coastal areas, among others; Coastal areas receive negative impacts in the form of pollution, sedimentation, and changes in the hydrological regime due to human activities \& development on land and also the high seas, vulnerable coastal areas (vulnerable) to environmental changes.12 The impact of this environment is greatly felt by the community. Development that does not consider all aspects of the environment, socio-cultural community, urban planning, and carrying capacity makes the image of development to be negative scourge for coastal communities.

Makassar City is one of the regencies/cities among 13 regencies/cities, in 10 provinces, which was chosen as the location of the Coastal Community Development Project - The International Fund for Agricultural Development (CCDP IFAD). This is based on the success of the region in its previous participation of conducting marine and fisheries activities. This includes the commitment and financial support of the Makassar city government to increase the income of coastal and small islands' communities based on its potential in increasing the added value of the results of marine and other fisheries products, and increasing the activities of the project to be disseminated.

We need to know that the CCDP IFAD is a program of The International Fund for Agricultural Development (IFAD) which is a special United Nations (UN) institution which was established as a financial institution in 1977. IFAD was one of the results of the decision of the 1974 International Food Conference. The conference was a response to the food crisis which mainly affected countries in Africa in the early 1970s. The conference agreed to establish an international financial institution that functions as an agency to fund agricultural development. ${ }^{13}$

Indonesia's membership in IFAD provides various benefits, including Indonesia being able to obtain program assistance through projects including financing in the form of long-term loans (40 years) with low interest; IFAD projects are aligned with the

10 Bambang Waluyo, 2008, Penelitian Hukum dalam Praktek, Jakarta: Sinar Grafika, p. 9

11 Peter Mahmud Marzuki, 2005, Penelitian Hukum, Prenadamedia Group Jakarta, Revision Edition, p. 35

12 Jian Setiawan, Pendekatan Sosiologi Masyarakat Pesisir di Makassar Sulawesi Selatan, Article of 2015.

13 See https://www.kemlu.go.id/rome/id/arsip/lembar-informasi/Pages/INTERNATIONAL-FUND-FORAGRICULTURAL-DEVELOPMENT-IFAD.aspx 
National Medium-Term Government Plan (RPJMN) and are targeted specifically at poor communities in remote agriculture-based areas; IFAD organizes workshops on data collection and information dissemination on IFAD projects for better implementation of projects in the future: Indonesia receives input on poverty reduction, especially in marginal areas in developing countries.

IFAD assistance/loans up to 2011 were around US \$ 776.3 million, of which US \$ 387.7 million were "loans" and consisted of 14 projects. At the end of 2011, there were 3 (three) projects that had not been completed in Maluku and North Maluku, Central Sulawesi and the National Community Empowerment Program (PNPM) Project. Currently, there are 4 programs running under the model of Indonesia's loan financed investment projects as follows:

1. Rural Empowerment for Agricultural Development Programme in Central Sulawesi

2. PNPM - National Programme for Community Empowerment in Rural Areas

3. Smallholder Livelihood Development Project in Maluku and North Maluku

4. Coastal Community Development Project (new projects agreed during the Executive Board meeting in September 2012).

Furthermore, in Makassar City, 15 coastal villages were developed, out of these 15 villages 9 villages were selected, 3 in the first year (2013), namely lakkang, Cambaya, Tanjung Merdeka and 6 in the second year (2014), namely Barombong, Untia, Buloa, Tallo, Barrang Caddi and Kodingareng based on criteria, among others:

1. Minimum poverty rate at each location is $20 \%$;

2. Motivation and success in participating in previous programs;

3. Potential for the production and value added of marine and fisheries; and

4. The inclusion of small islands in each regency/city location that has an island.14

The commitment shown by the Makassar City Government is one of the efforts to increase the income of coastal and small islands' communities so that welfare can be felt by the community. The welfare is a mandate in Law of the Republic of Indonesia Number 11 Year 2005 concerning ratification of the International Covenant on Economic, Social, and Cultural Rights 1966.

To realize community empowerment, welfare and independence, the community needs to be supported by participatory development management. In the order of the government, an honest, open, responsible, and democratic government is needed. Whereas in society, it requires an open order that provides opportunities for community participation in the decision-making process for the common good. Development and empowerment of rural communities living in coastal areas has become very strategic to cultivate the diversity of marine potential that can be maximized.

Empowerment of rural communities living in coastal areas should be directed towards community empowerment related to the potential of the village itself. Empowerment for coastal communities is intended to improve their welfare by providing supplies and knowledge so that they can more fully multiply the potential of available natural resources by applying appropriate technology, so that the production of marine products can increase their yields and incomes. Therefore, the key to empowering rural communities living in coastal areas is the fishermen themselves. Namely by making

14 Ibid. 
fishermen as partners in community empowerment programs, so that it will foster motivation and accelerate the implementation of the objectives of the empowerment program.15 The non-cooperative attitude of the fishermen is also one of the nontechnical obstacles in empowering through programs launched by the central and regional governments.

Empowerment of rural communities is one of the efforts to improve community welfare through several activities including increasing community initiatives and selfhelp, environmental improvement, developing village-owned businesses, developing village financial lembanga, and participating in activities that can increase the community's ability to increase their production. Community empowerment efforts should be able to play a role in improving the quality of human resources and changing people's behavior to achieve a better standard of living.

\section{The Implementation of Local Government Policy}

The International Fund for Agricultural Development (IFAD) in Makassar has provided guidance to several groups starting in 2013 and ending in 2017. However, the Agriculture and Fisheries Service in Makassar City continues to improve its assistance to coastal communities which is carried out with capacity assistance in conducting: Arrest, Aquaculture, Marketing, Resource manager.

Community empowerment activities are usually carried out with the socialization of environmentally friendly fishing gear, counseling of fishing gear use of hazardous chemical fish drugs must remain in levels that still pay attention to environmental sustainability, for the empowerment of small fishermen. Conducted by socialization, counseling, assistance, grants, borrow and use, for assistance are usually given production facilities such as feed and seeds.

Empowerment activities for coastal communities are still under the authority of the municipal fisheries service, in contrast to those related to the development of coastal areas and small islands which are the province's jurisdiction in terms of supervision and management, related to natural resource issues, supervision, fulfillment of infrastructure to provincial authority, in certain cases the provincial maritime and fisheries service becomes an extension of the ministry so that the type of authority carried out by managing deco centration funds, co-administration tasks, the authority for infrastructure procurement by the provincial fisheries service, for clean water, electricity.

Some factors that caused poverty in coastal communities according to the assessment of the Makassar City Agriculture and Fisheries Office:

1. Dependence on natural conditions, Traditional fishermen generally catch fish using simple fishing tools so that if the season is strong the waves do not go to sea and make income less, automatically if in the catching season they occur they have to cover expenses in the lean season, which usually they have borrowed money from moneylenders.

2. Consumptive lifestyle, coastal communities generally do not think long but only think the needs of today.

15 Simela Marvel Hardiknas Makagingge, et al, (2017). Pemberdayaan Masyarakat Pesisir dalam Meningkatkan Kesejahteraan di Desa Mahumu Dua Kesamatan Tamako Kabupaten Kepulauan Sangihe, Jurnal Eksekutif Universitas Sam Ratulangi, 6 (1): 3. 
3. Inadequate equipment used, small vessels, insufficient nets and other equipment repairs.

4. Access to insufficient capital, they prefer to borrow from the retainer who prioritizes the family rather than the bank method that is sometimes forced.

5. Inadequate quality of education, structural profession that occurs Because they are fishermen, even children only have the expertise of the fishing profession.

6. The circle system in the coastal community environment that forces a child of fishermen sometimes prefers to work to help the family so that it can earn income so that this can hamper the course of education for fishermen's children.

7. A fisherman's child is bound to the skipper as a place to obtain means of production so that he continues the vicious cycle of his father's dependence on the owner of the capital.

In 2018 the fisheries service provided production facilities in the form of nets to fishermen groups while in the previous year the ship and boat equipped with machinery were distributed in 2017. The fisheries service in formulating the policy prior to doing the Mapping conducted on the less prosperous coastal communities, so departing from the mapping results obtained then formulated a policy for example in the development of human resource capacity training will be carried out in areas that most need these areas are usually still lagging behind like Untied, the local government is the most relevant party to be responsible for improving welfare.

The average fisherman has a small boat with a size below 5 GT, while to get an expensive fish commodity Fishermen need a boat larger than 5 GT, because the location of the fishing boat is getting farther out to sea. Various needs of fishermen in Makassar such as fishing gear, fish finder, strong and long net navigation to increase fishing capacity. Unlike the case with Farmers because they need production facilities such as shrimp, fish, seaweed, feed and fertilizer to repair ponds and sluice gates.

All parties are certainly responsible for improving the welfare of coastal communities, and of course for special agencies whose authority is in direct line with coastal communities, of course they have more responsibilities than others such as the Tourism Office responsible for identifying and assisting coastal communities to provide alternative work that can improve the welfare of coastal communities, the role of environmental agencies related to AMDAL (Environmental Impact Analysis) and provide assistance related to fishing methods that are more environmentally friendly so as to maintain the preservation of the surrounding environment to increase fish populations in the Makassar coastal area. In addition, the role of the industry and trade department is to be able to provide assistance to the processing and marketing of products.

Conformity with the needs of government policies is needed so that the assistance provided can be maximized. For fishermen they need more like: Net, Cantrang Net, This tool drift net is used in certain seasons, besides the 5 PK engine capacity used by fishermen is generally not comparable to the boat used which requires $20 \mathrm{PK}$, so it is not too maximal to use by the community, so it is necessary to adjust the capacity of the engine with the ship to better maximize the catch.

In addition there are some high economic commodities, such as crab crab. The help of crab crab nets will greatly help fishermen because of its very high economic value so that it further improves the community's economy. The average income per day in certain conditions and even fishermen income can reach 1 million per day in certain 
seasons, but of course this is not every day they can feel, with a consumptive culture of society and not too planning to save money obtained so that makes the community too.

In addition to physical assistance in fishing gear, a health insurance policy will greatly help to reduce fishermen's expenditure. Distance of health access from community settlements also determines the optimal policies implemented.

In addition, the formation of a group of fishermen initiated by the government or independently by the community, helped strengthen community resilience from the economic vulnerability of coastal communities. With the presence of their group, it will be more in harmony to help each other among fishermen, besides that government assistance can be more easily distributed either in the form of equipment or capital to the community in the form of cooperatives with light fees so that it can become an economic safety net for coastal communities.

The importance of government policies that pay attention to their impacts on coastal communities. Reclamation in the city of Makassar is one of the policies that harm fishermen. This is because the reclamation pile is blocking the fishermen's fishing lanes, so they have to spin to get to the middle of the sea which is the location of fishing. In addition of reclamation also affects the marine ecosystem in the waters of Makassar, so that it has an impact on the reduction in the catch of fishermen's fish. In the reclamation development policy in the city of Makassar, from the results of a study by the Makassar Legal Aid Institute, it was identified that 43 heads of households who had lived for 34 years in that location had to be displaced due to reclamation. no longer able to finance their education ${ }^{16}$. The government must consider the impact that will occur on the most vulnerable groups of society, such as fishermen so that they can still continue to make a living.

The impact of Reclamation for fishermen makes fishermen need additional costs to buy gasoline. If in the past we only needed one liter of gasoline now they need double fuel. Influence of income that occurs after the presence of the reclamation, because living around the river mouth so they must pay attention to tides, this is compounded by silting of the river which makes the community if late in entering then he cannot go home, Trash by the river is also hampering, Reclamation is detrimental, because only a handful of people who benefit while we (coastal communities) do not benefit, At the time of the socialization of this reclamation development did not ask for community consideration.

In addition, the thing that is detrimental to fishermen is also other fishermen who use environmentally unfriendly fishing gear such as trawlers who use very large nets, which plunder all available resources, from small fish to fish, to the detriment of other fishermen. In addition there are still many who also use fish bombs, thus reducing the population of seaweed.

Finally, the formulation of coastal area development policies must use an integrated coastal area management approach (Integrated Coastad Management) with the aim of strengthening and harmonizing development in the coastal areas at the government level and in various other sectors at the legislative level, so that the development of the economic sector with the preservation of coastal areas takes into account characteristics

16 Suharno, et al (2017), Keadilan \& Demokrasi Tahun 2016 Negara Balik Badan Refleksi Penegakan Hukum, HAM \& Demokrasi di Sulawesi Selatan, (Annual Report 2016), LBH Makassar, p 9-10 
and uniqueness of each region ${ }^{17}$. Development policies that disregard the rights of fishermen are certainly in conflict with efforts to fulfill the rights of the fishermen themselves. So the most important thing in government policy towards coastal communities, is to prioritize the interests of fishermen who are vulnerable and in urgent need of protection by the government.

\section{Conclusion}

The Makassar City Fisheries Department in formulating policies prior to conducting Mapping conducted on less prosperous coastal communities, so departing from the mapping results obtained then formulating policies for example in developing human resource capacity training will be conducted in areas that need it most usually in areas that are most a poverty pocket, the local government is the most relevant party to be responsible for improving the welfare of the community.

The implementation of the Makassar City Government's policy towards coastal communities is that the Makassar City Fisheries Service provides production facilities in the form of nets for fishermen groups. In 2018, while in the previous year, ship aid and boats equipped with engines were distributed in 2017. All parties are certainly responsible responsible for improving welfare for coastal communities, each related department provides policies that are tailored to the needs of the community and the duties and functions of each related department. In addition it is important to evaluate government policies that harm coastal communities. The implementation of the reclamation policy which is detrimental to fishermen is certainly counterproductive to other policies aimed at the welfare of coastal communities.

\section{Acknowledgments}

This article is part of the results of the research funded by the Institute for Research andCommunity Service (LP2M) Hasanuddin University Year 2018 with UNHAS Leading Research Scheme (RUNAS).

\section{References}

Book:

Waluyo, B. (2008). Penelitian Hukum dalam Praktek, Jakarta: Sinar Grafika.

Marzuki, P.M. (2005). Penelitian Hukum, Jakarta: Prenadamedia Group.

Supridi \& Alimudin. (2001). Hukum Perikanan di Indonesia, Jakarta: Sinar Grafika.

Journal Articles:

Asis, A. et al. (2016). Strategic policy of the Government of Indonesia In the Field of Maritime and Fisheries Affairs, International Journal of Scientific and Research Publications, 6 (12): 238.

(2017). Hak-Kewajiban Nelayan dan Kelompok Nelayan Menurut UU RI Nomor 7 Tahun 2016, Jurnal Hukum Justitia 5 (1): 53.

(2018). Persoalan Hukum Nelayan dan Kelompok Nelayan di Kabupaten Takalar, Jurnal Ilmu Hukum The Juris, 2 (2).

17 Safa'at, R., \& Yono, D., (2017). Pengabaian Hak Nelayan Tradisional Masyarakat Hukum Adat Dalam Politik Perundang-Undangan Pengelolaan Sumber Daya Pesisir, Jurnal Arena Hukum, 10 (1): 48-49. 
Dirhamsyah, D. (2006). Indonesian legislative framework for coastal resources management: a critical review and recommendation. Elesevier: Ocean $\mathcal{E}$ Coastal Management, 49(1-2): 68-92.

Safa'at, R., \& Yono, D., (2017). Pengabaian Hak Nelayan Tradisional Masyarakat Hukum Adat Dalam Politik Perundang-Undangan Pengelolaan Sumber Daya Pesisir, Jurnal Arena Hukum, 10 (1): 48-49.

Simela Marvel Hardiknas Makagingge, et al, (2017). Pemberdayaan Masyarakat Pesisir dalam Meningkatkan Kesejahteraan di Desa Mahumu Dua Kesamatan Tamako Kabupaten Kepulauan Sangihe, Jurnal Eksekutif Universitas Sam Ratulangi, 6 (1): 3.

Suharno, et al. (2017). Keadilan \& Demokrasi Tahun 2016 Negara Balik Badan Refleksi Penegakan Hukum, HAM \& Demokrasi di Sulawesi Selatan, (Annual Report 2016), LBH Makassar.

World Wide Web:

Kata Data, Bagaimana Tingkat Kesejahteraan Masyarakat Pesisir Indonesia?, Kata Data News and Research Edisi 16 January 2018

Munawir, Menilai Kepatuhan Nelayan Kabupaten Takalar dalam Perbaikan Perikanan Karang, WWF Indonesia, 2017, accessed at https://www.wwf.or.id/?54362/ Evaluating-the-Fishermens-Level-of-Compliance-in-Takalar-Regency-in-Coral-FisheryImprovement

The Ministry of Foreign Affairs of the Republic of Indonesia. https://www.kemlu.go.id/rome/id/arsip/lembar-informasi/Pages/INTERNATIONALFUND-FOR-AGRICULTURAL-DEVELOPMENT-IFAD.aspx

The Ministry of Marine Affairs and Fisheries Republic of Indonesia. Meningkatkan Kesejahteraan Masyarakat Pesisir, Available online at: https://news.kkp.go.id/ index.php/meningkatkan-kesejahteraan-masyarakat-pesisir/ Accessed on Sept 22, 2015.

\section{Conflict of Interest Statement:}

The author(s) declares that the research was conducted in the absence of any commercial or financial relationships that could be construed as a potential conflict of interest.

Copyright (C) 2020 HALREV. All rights reserved. 